\title{
A Socially Contextualized Model of African American Identity: Possible Selves and School Persistence
}

\author{
Daphna Oyserman \\ Wayne State University
}

\author{
Larry Gant \\ University of Michigan
}

\author{
Joel Ager \\ Wayne State University
}

\begin{abstract}
Schooling, critical to the transition to adulthood, is particularly problematic for urban and minority youths. To explore predictors of school persistence the authors propose a socially contextualized model of the self. Strategies to attain achievement-related possible selves were differentially predicted for White and Black university students (Study $1, n=105$ ). For Whites, individualism, the Protestant work ethic, and "balance" in possible selves predicted generation of more achievement-related strategies. For Blacks, collectivism, ethnic identity, and low endorsement of individualism tended to predict strategy generation. In middle school, performance was predicted by "gendered African American identity schema," particularly for females (Study $2, n=146$ ), and the effects of social context appeared gendered (Study 3,n=55). Balance in achievement-related possible selves predicted school achievement, especially for African American males (Study $4, n=55$ ).
\end{abstract}

Adolescence has sometimes been conceptualized as a time of unfettered identity negotiation. Youths are said to "try on" various identities, convey various self-conceptions to others, and receive moderating feedback on these conceptions (Cantor \& Zirkel, 1990; Stryker, 1987). In this way youths synthesize childhood identities with what they know of their skills and abilities and construct adult selves that are at once plausible and at least reasonably satisfying (Cantor, Norem, Niedenthal, Langston, \& Brower, 1987; Curry, Trew, Turner, \& Hunter, 1994). The self thus constructed functions to (a) lend meaning and organization to experiences-thoughts, feelings, and actionsand (b) motivate action by providing incentives, standards, plans, strategies, and scripts for behavior (Cantor \& Zirkel, 1990; Markus \& Wurf, 1987; Oyserman \& Markus, 1993, in press).

These socially constructed selves rely heavily on the backing of important others in the social environment, both as models-what others are now, I can become-as purveyors of messages about which characteristics of the self are valued and important, and as resources, providing experiences of success and competence in roles relevant to adult statuses and attainments (Crane, 1991; Markús, Cross, \& Wurf, 1990; Ogbu, 1991; Oyserman \& Markus, 1993, in press). Others in the social environment provide information about how to be-a woman, a family member, and so on (Oakes \& Turner, 1990; Stryker,

Daphna Oyserman, Merrill-Palmer Institute, Wayne State University; Larry Gant, School of Social Work, University of Michigan; Joel Ager, Department of Psychology, Wayne State University.

Correspondence concerning this article should be addressed to Daphna Oyserman, Merrill-Palmer Institute, Wayne State University, 71-A East Ferry Road, Detroit, Michigan 48202.
1987). They provide models for emulation and feedback about the kind of self one might become (Oyserman \& Markus, 1993, in press; R. L. Taylor, 1989). The social environment is also the context in which youths are provided with educational, economic, and other resources, sometimes termed cultural capital, which enable them to obtain the skills and characteristics necessary to become the kind of adult valued in their sociocultural niche (Lamont \& Lareau, 1988; Ogbu, 1991).

For many youths, the self one could be as an adult is rapidly bounded by an increasingly detailed array of plausible alternatives given past and current attainments and resources available in one's sociocultural context (Anderson, 1991; Crane, 1991; Oyserman \& Markus, 1990b). Thus, though sometimes conceptualized as a psychosocial moratorium in which a limitless array of identities are "tried on," adolescence seems to involve a general restriction of alternatives for many youths. This bounding process tends to involve a reduction in one's belief in one's ability to succeed in school and a parallel decline in interest and involvement in school (Freedman-Doan, Arbreton, Harold, \& Eccles, 1993), as well as a sharp increase in delinquent involvement, contraceptive risk taking, and increased risk for depressive symptomatology (Cernkovich \& Giordano, 1992; Harter, 1990; Henggeler, 1991; Jessor, Donovan, \& Costa, 1992 ). In the present studies, we used a socially contextualized model of the self to formulate hypotheses about the selves youths construct and the impact of these selves on school persistence and attainment.

\section{Increased Risk in the Adolescent Transition for Urban African Americans}

Young Black males are at increased risk for school failure and dropout (Corley, Cernkovich, \& Giordano, 1989; Solorzano, 
1992), arrest, and incarceration (Cernkovich \& Giordano, 1992; Elliott, Huizinga, \& Morse, 1988; Loeber et al., 1993). In addition, being Black in America is likely to mean being an urban dweller (Jackson, 1991), and inner city youths must seek out and sustain a sense of positive possibilities for the self within a stark social context of ever-shrinking employment opportunities. For African Americans, a "job ceiling" has been described such that movement out of entry-level jobs is less likely. In addition, the number of African Americans living in or near poverty has increased more rapidly than those in the middle class. More African American young men are in jail and prison settings than in college or university settings (Tripp, 1991; Steele, 1988). African American women are clustered in jobs with lowest pay and status (Herring \& Wilson-Sadberry, 1993); and men are overrepresented in low-status, unstable, and low-wage jobs, are more likely to be unemployed, and may be overrepresented in the population of individuals no longer counted in unemployment statistics because, having given up on finding a job, they no longer actively seek one (Allen \& Farley, 1985; Bowman, 1991). Thus, African American adolescents are likely to experience social contexts that do not afford construction of plausible futures in which school success leads to occupational success in adulthood. This means that construction and maintenance of possible selves in these domains will need to be especially effortful and that youths will need to take into account problems and barriers in envisioning what is possible for them. Therefore, as we explain below, we believe that the process of identity construction for African American youths shows in high relief the implications of a social constructed identity model both for the content of the self and its behavioral implications.

\section{The Sociocultural Context of the Self}

Most current models of the self are decidedly asocial (D. M. Taylor \& Dube, 1986; Turner, Hogg, Oakes, Reicher, \& Wetherell, 1987). These models present a view of the self as an autonomous, bounded, independent entity created by the individual. Such a view is well buttressed in Western, especially White middle-class, cultural assumptions about the nature of personhood (Fiske, 1990; Oyserman, 1993; Shweder, 1991). Yet this asocial view of the self has been increasingly criticized as giving short shrift to the context within which identities are constructed (e.g., Trew \& Bensen, in press) and the impact of social context on what is viewed as self-defining (Turner, Oakes, Haslam, \& McGarty, 1994). Far from independently crafting a self of one's own choosing, identities are negotiated within the framework of one's central social contexts (Oyserman \& Markus, in press). As depicted in Figure 1, identities are constructed from the scaffolding of one's social contexts and are specifically instantiated in relationships with others. The scaffolding may be clearly accessible to the individual ("My friends and I all want to be") or may have an invisible yet ever-present effect (e.g., the impact of gender on all aspects of others' responses to the self).

In the case of African American youths, identity negotiation involves the dual task of assembling a positive sense of self while discrediting negative identities attributed to African American males and females (Brown, 1990; Crocker \& Major, 1989;
Kirschenman \& Neckerman, 1991). These imputed negative identities cannot simply be ignored or viewed as irrelevant to the self, because they are woven into important life domains (Showers, 1992a, 1992b). Failing to take these identities into account would seriously impede basic functions of the self: its ability to organize, interpret and integrate experience, and regulate affect. This stereotype vulnerability (Spencer \& Steele, 1992; Steele, 1988), or need to consistently disavow groupbased negative feedback, is proposed to have important consequences for identity construction, making self-protection an important focus for African Americans.

\section{Structure and Function of the Self}

As depicted in Figure 1, and consistent with earlier work coining the concept of ethgender - the social space created by the interweaving of gender and ethnicity (Haw, 1991; Martinez \& Dukes, 1991) - we propose that African Americans develop a gendered African American identity schema to (a) make sense of the self as a group member; (b) lend meaning and organization to current and historical racism, limited opportunities, and successes of African Americans; and (c) organize self-relevant knowledge about personal effort and its meaning to an African American male or female. Congruent with the cognitive development that occurs during this period, adolescents are able to conceive of themselves along multiple dimensions; can begin to visualize various hypothetical, possible selves; and can take multiple perspectives on the self (Csikszentmihalyi \& Larson, 1984; Damon \& Hart, 1986; Hart \& Damon, 1986; Harter, 1990; Harter, Marold, \& Whitesell, 1992; Moretti \& Higgins, 1990; Strauman \& Higgins, 1987). Derived from one's experience in the social contexts of family, peer group, school, and neighborhood, these knowledge structures or self-schemas are not only generalizations of one's past characteristics, actions, and skills, but also claims of responsibility for current and future characteristics, actions, and skills in a particular domain (Cantor \& Zirkel, 1990; Markus \& Wurf, 1987).

Possible selves, the future-oriented components of the selfschema, are viewed as the components critical for putting the self into action (Oyserman \& Markus, 1990a). These selves are derived from past experience and from the positive and negative prototypes and images individuals are urged to attain and warned to avoid, respectively. The academic and occupational possible selves of early adolescence function to organize and focus youths' attention on what sorts of future selves are plausible and how they might best obtain these selves, motivating goalfocused behavior.

Balance in possible selves or construal of both positive, expected selves and to-be-avoided, negative possible selves in the same content domain has been posited as an important tool for behavior control. Youths with balanced possible selves in a particular domain are assumed to have a positive self-relevant goal for which to strive in that domain and also to be acutely aware of the personally relevant negative consequences of failing to attain that goal. This balance may preserve motivation to attain the positive possible self and avoid the negative possible self, leading to increased perseverance.

Balance in possible selves may also decrease the range of 


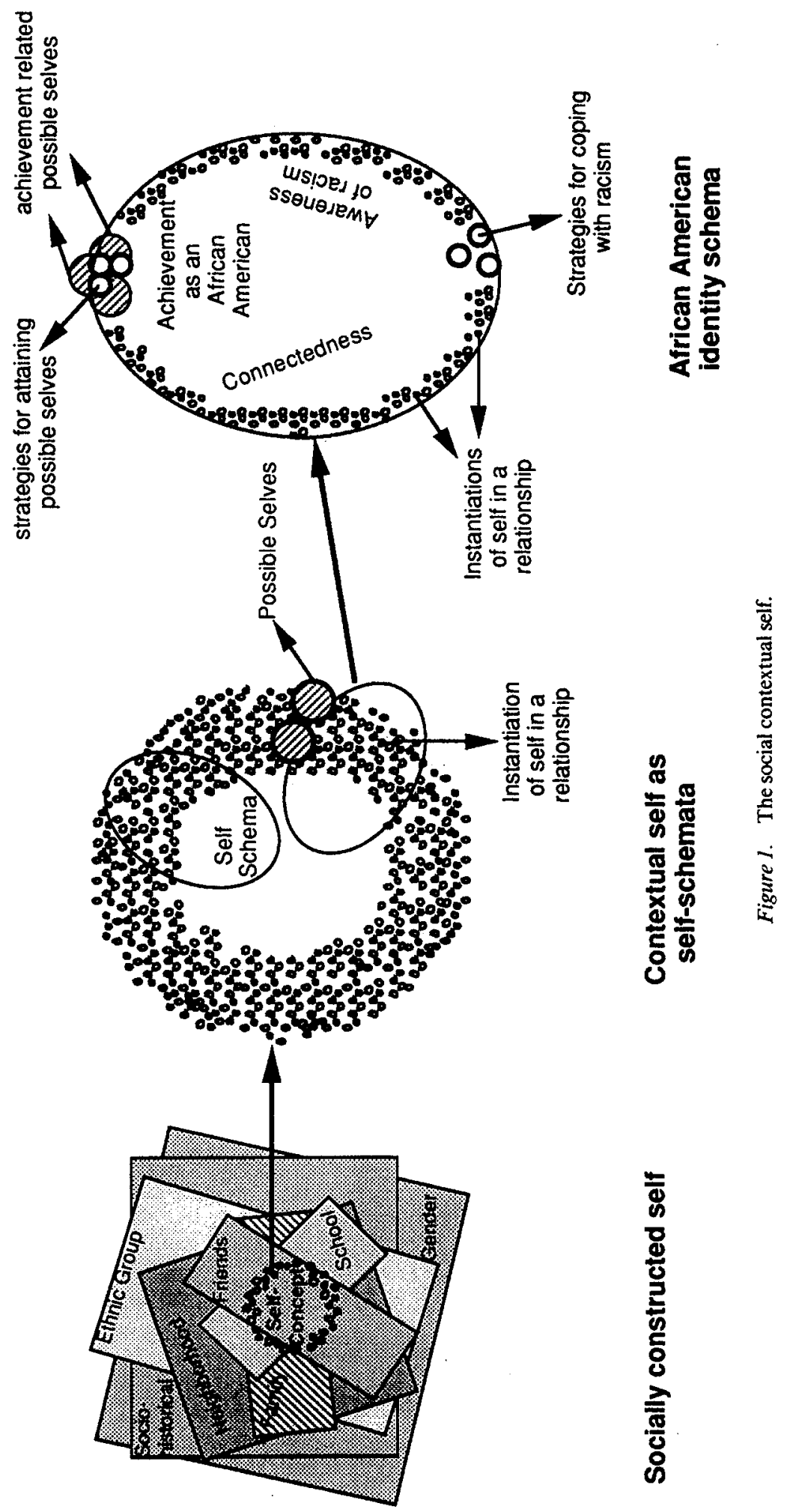


strategies deemed acceptable in attempting to attain positive possible selves, as only strategies that both lead to increased chances of attaining the positive and avoiding the negative will be deemed acceptable. Non-normative or deviant strategies, such as delinquency, which may simultaneously increase the short-term plausibility of positive possible selves (e.g., me as daring, independent) and make to-be-avoided selves (e.g., me as in jail) more likely in the longer run, are more likely to be eschewed by youths with balanced possible selves in a particular domain (Oyserman \& Markus, 1990a, 1990b; Oyserman \& Saltz, 1993).

\section{Sociocultural Context of Adolescence for Urban African Americans}

\section{Racism}

When asked whether being Black makes a difference, middle school youths make statements such as "Sometimes I catch people staring." Racism involves a sense of being excluded or negatively judged and a sense that because of one's group membership one's chances are limited. Awareness of racism allows one to draw negative interactions away from the self and discount negative self-attributions to be made as a result of setbacks or failures.

In current American society, individuals are valued and value themselves to the extent that they achieve success-academic, occupational, or material (e.g., Giorgi \& Marsh, 1990). When success in academic and occupational domains is unlikely, efficacy, one's sense of competence, suffers (Gecas, 1989). Lack of efficacy has been related to reduced sense of control, autonomy, self-determination, and task persistence (Bandura, 1986). Therefore, past and current racism may make creation of an identity that includes independence, success, and achievement as they are normatively defined a daunting task (Bowman, 1990), particularly for African American males. Perhaps that is why self-efficacy, not self-esteem, is lower among African Americans, and neither self-efficacy nor school achievement is related to self-esteem for African American youths as it is for Whites (Hare, 1988; Hughes \& Demo, 1989). Although it seems possible to build a sense of esteem based on interpersonal relationships and not on achievements in school or work, development of self-efficacy in this country is strongly related to occupational prestige and academic achievement (Hughes \& Demo, 1989).

\section{Gender}

The effects of racism are subtle and complex (Kirschenman \& Neckerman, 1991; Tripp, 1991). Though systematic evidence is sparse, it appears that the effects of racism may be gendered. Outside the community, African American males are likely to be viewed as violent, suspicious, and dangerous (Hunter \& Davis, 1992; Loring \& Powell, 1988). In school, African American males must negotiate their identities by disconfirming the "four d's: dangerous, deviant, dumb, and deprived" (R. Taylor, 1991). In the context of employment, African American men are stereotyped as lazy, poor workers (Gibbs \&
Hines, 1989; Wilson, 1987). African American women, on the other hand, are often stereotyped as either nurturing, patient, and self-effacing "mammy" figures; as sexually promiscuous; or as assertive to the point of aggression (Brown-Collins, 1993; West, 1993). In addition to gendered patterns of racism, gender appears to play an important role in socialization in the family. Although African Americans tend to socialize their children in terms of egalitarian gender roles (Littlejohn-Blake \& Darling, 1993), parental expectations and behaviors appear to differ somewhat for boys and girls (J. McAdoo, 1991; Bernstein, 1991). African American mothers have higher educational aspirations for their daughters than for their sons (Solorzano, 1992). They are more likely to supervise their daughters (Simmons, Switzer, \& Zhou, 1993) and to have a close, intimate relationship with them and may also be more likely to provide their daughters with the specific skills they believe they will need to enter the workforce and provide for their children (Gibbs \& Hines, 1989; R. Taylor, 1991). A folk saying speaks to possible socialization differences: "Black mothers love their sons but raise their daughters."

In thinking about their identity, African American women remember their parents focusing on African American community and heritage while men are more likely to report receiving parental messages about individual initiative, action, and ability to overcome difficulties (Bowman \& Howard, 1985). A retrospective study of Black and White women who attained professional status found that African American women were more likely to remember their parents, kin, and community as encouraging them to remain in school and succeed professionally. Relatedly, Black women were more likely to believe that they should contribute to their kin and community than did Whites (Higginbotham \& Weber, 1992).

\section{Connectedness}

High levels of familialism, including maintenance of fictive kin networks, have been reported in the literature (e.g., Asante, 1987, 1988; H. P. McAdoo, 1988). Familialism involves viewing the family and family relationship as centrally self defining and viewing social obligations to family as ongoing and normative. Kin networks are often the operationalization of familialism. African American women are reported to be at the center of these kin networks, receiving and providing support and maintaining communication across households and generations (Jackson, 1991). Family has also been described as the first line of defense against a discriminating environment (Giordano, Cernkovich, \& DeMaris, 1993). Familialism and discrimination may function to make parent-adolescent relations closer and more intimate among African Americans than among Whites (Cernkovich \& Giordano, 1987; Giordano et al., 1993; Jackson, McCullough, \& Gurin, 1988). Parent orientation may be part of a larger focus on family and greater continuity of family and kin contact and support over the life span (H. P. McAdoo, 1988; Nobles, 1988).

The family context is likely to have an important impact on content and structure of one's African American identity schema (Parham, 1989). Data from the national study of Black Americans (Thornton, Chatters, Taylor, \& Allen, 1990) show 
that approximately two thirds of parents attempt to teach their children about African American identity and that a similar percentage of adolescents and young adults perceive their parents as attempting to teach them African American identity (Bowman \& Howard, 1985). Youths who perceive their parents, primarily their mother, as attempting to teach them African American identity have a more positive attitude about school and are more likely to feel efficacious about school and aspire to further education (Bowman \& Howard, 1985). Therefore, a sense of self as part of kin and community, as giving and receiving from the group, is hypothesized as a second component of African American identity, which provides a sense of meaning and purpose and ties the self to normative strategies for goal attainment, particularly school achievement.

\section{African American Identity}

\section{Centrality and Implications}

Though a complete review of the far-flung literature on African American identity (e.g., Akbar, 1991; Asante, 1987, 1988; Cross, 1991; Gibson \& Ogbu, 1991; H. P. McAdoo, 1988; Parham, 1989; Porter \& Washington, 1989) cannot be presented, a central theme is that this identity is a means of organizing and interpreting social experiences, regulating affect, and controlling behavior and is therefore a central part of one's selfconcept.

African American identity has been related to better functioning whether measured by lack of depressive symptomatology (Chestang, 1984), occupational attainment (Broman, Jackson, \& Neighbors, 1989; Demo \& Hughes, 1990), or fewer behavior problems in school (Rotheram-Borus, 1990). Lack of African American identity is assumed to result in misinterpretation of social experience, self-blame, and guilt for limited occupational, educational, and economic success (Azibo, 1991; Gibson \& Ogbu, 1991; Robinson \& Ward, 1991; Sanders Thompson, 1991). Similarily, ignoring racism as a force in one's everyday life has been connected with reduced well-being and increased depressive symptomatology (e.g., Carter, 1991).

\section{Content and Structure}

Two components of the hypothesized gendered African American identity schema-connectedness with the Black community and heritage and awareness of racism-are described in the literature.

\section{Connectedness}

African American identity has been described as a sense of self as a member of an African American community, heir to a tradition of communalism, familialism, and kin support (Akbar, 1991; Asante, 1987, 1988), a worldview focusing on spiritualism and connectedness with the social environment rather than individual-based competition with, and exploitation of, the environment (Akbar, 1991; Parham, 1989).

\section{Racism}

Black identity has been described as a sense of self as subject to prejudice, racism, and exclusion from opportunities by White society (Gibson \& Ogbu, 1991; Tripp, 1991).

In the proposed model, we suggest a third component of African American identity, conceptualization of achievement as an African American. This identity component is necessary to integrate the awareness-of-racism and connectedness components of African American identity with the individualistic, Protestant work ethic orientation of American society. To the extent that individual achievement is contradictory to one's connectedness with the group, and racism is ignored, youths will find school achievement problematic (Fordham, 1988). Therefore, achievement must be conceptualized as occurring within the context of being African American (Azibo, 1991; McCombs, 1985; Ogbu, 1991; Tripp, 1991). This may be particularly important for females, for whom the relational component of identity may be particularly important (Markus \& Oyserman, 1989). By conceptualizing achievement as embedded within one's sense of self as an African American, youthsand especially female youths-will not experience contradiction and tension between achievement and being African American. When this component of the African American identity schema is not present, achievement may be culturally inverted and viewed as being White, not Black (Ogbu, 1991).

We posit that gendered African American identity schemas that contain three components-sense of community embeddedness, awareness of racism, and individual effort as an African American (including academic and occupational possible selves ) - will increase school persistence and performance. Our review of the literature suggests that African American identity may serve different purposes for teenage males and females. For males, African American identity seems more likely to focus on action, struggle, and survival, whereas for females the focus seems to be on school attainment and attention to kin and the wider African American community and its traditions and institutions (Levin \& Taylor, 1993). In addition, features of women's selves such as the importance of close interpersonal relationships, intimacy, and connectedness with others, and the value of caring and cooperation rather than competition (e.g., Harter, 1992), are congruent with African American values and heritage. For females, African American identity may provide a way to be both interdependent and also achievement oriented. To begin to explore the hypothesized gendered African American identity schema and its connection with school performance and persistence, we conducted four studies in the city of Detroit.

\section{Study 1: Socially Contextualized Identity and School Performance}

The purpose of this study was to begin to explore the ways in which socially contextualized identity relates to school performance. Overlapping constructs such as ethnic identity (Giordano et al., 1993; Phinney, 1992), individualism, the Protestant work ethic, and collectivism (Giorgi \& Marsh, 1990; Katz \& Hass, 1988; Oyserman, 1993) all contain some notions 
about what it means to do well and under what conditions success is likely. We hypothesized that Black and White students would differ in their level of collectivism, Protestant work ethic, and endorsement of an ethnic identity measure, with African American students rating themselves higher in collectivism and ethnic identity and White students more likely to endorse the Protestant work ethic. Our model suggests that school achievement involves more effortful identity construction tasks for African American students and that an embedded or connected identity would free the African American students to focus on achievement without internal conflict about whether achievement pulls one out of the group and is a form of "acting White." We assumed that students who had developed more strategies to obtain their achievement-related possible selves would be better equipped to move toward these goals. Because identity construction was assumed to be more effortful, we hypothesized that Black students would have more strategies for attaining achievement-related possible selves and that for Black students, a sense of connectedness to the group-collectivism-would predict strategies to attain achievement-related possible selves. For White students, we hypothesized that commitment to achievement as centrally defining and as controlled by the self, that is, individualism and Protestant work ethic beliefs, would predict development of strategies to attain achievement-related possible selves.

\section{Method}

\section{Participants}

Respondents were 118 Wayne State University undergraduate psychology students (63 White, 42 Black, and 16 from other diverse groups) who completed an anonymous questionnaire on self and identity as part of their course requirements. Only data from the 105 White and Black students were retained for analyses.

\section{Procedure}

Students filled out anonymous questionnaires containing open- and closed-ended questions. Open-ended questions focused on possible selves and strategies to attain them and were filled out before administration of the closed-ended identity questions that formed the ethnic identity, individualism, collectivism, and Protestant work ethic scales.

\section{Measures}

Possible selves. Students generated four or more possible selves (first the selves they expected to become and then the selves they were trying to avoid becoming) in response to open-ended probes about their expectations for the coming year ("Next year I expect to be...," Next year I want to avoid being ..."). Students were told that possible selves focused on current and plausible future self-descriptors. Possible selves were coded into one of five categories: achievement related (school or job), interpersonal relationships, intrapsychic traits or personality characteristics, attainment of material goods, and negative or non-normative self-descriptors, following Oyserman's coding strategy (Oyserman \& Saltz, 1993). Balance in possible selves was coded for each of these content domains. Coders were trained until interrater reliability, measured as percentage agreement, of $90 \%$ was obtained on the first third of the interviews. All interviews were double coded, and disagreements were discussed to obtain agreement (Oyserman \& Markus, 1990a; Oyserman \& Saltz, 1993). Analyses focused on the achievement domain.

Related identity constructs. Students also filled out a closed-ended Likert type ( 1 = strongly disagree, 5 = strongly agree), 7-item individualism scale (e.g., "I am a unique person, different from anyone else," [Oyserman, 1993] total $\alpha=.45$, Black $\alpha=.55$, White $\alpha=.44$ ), an 8item collectivism scale (e.g., "A mature person helps his/her group before all else," [Oyserman, 1993] total $\alpha=.65$, Black $\alpha=.63$, White $\alpha$ $=.66$ ), an 8-item Protestant work ethic scale (e.g., "A distaste for hard work shows weakness of character," total $\alpha=.63$, Black $\alpha=.60$, White $\alpha=.63$ [Katz \& Hass, 1988]) and an 8-item ethnic identity scale (e.g., "Only members of my own group can really understand me," modified from Giordano [1991], Phinney [1992], total $\alpha=.66$, Black $\alpha=.72$, White $\alpha=.54$ ).

Strategies to obtain possible selves. After generating possible selves, students were asked to check off the selves on which they were currently actively working and to write down what they were doing to become like selves they were trying to approach and to avoid becoming like selves they were trying to avoid. The number of strategies or activities thus described were coded by simply counting the number of strategies or activities students listed for each of the checked-off possible selves. Again, following the focus of the study, we analyzed only strategies in the achievement domain.

Following Higgins, Roney, Crowe, and Hymes (1994), we coded the number of strategies focused on obtaining positive expected selves separately from those focused on avoiding feared or to-be-avoided selves. Examples of the former strategies are "I am studying every night (except weekends)," and "I started taking a pencil and paper to all my classes and taking notes." Examples of the latter strategies are "I am trying to stop procrastinating by turning off the T.V. when I should be doing homework," and "I am getting to bed at a reasonable hour the night before morning classes."

\section{Results}

Although they did not differ in their extent of balance in possible selves, overall $F(1,103)=2.09, p=.15$, Black and White undergraduates did differ in the number of balanced possible selves that were in the achievement domain of school and/or work, $F(1,103)=4.15, p=.04$, with Black students having fewer such balanced achievement-related pairs of possible selves (achievement balance $M=0.64$ for Blacks and $M=0.92$ for Whites). Men and women did not differ significantly in regard to balance in possible selves.

The closed-ended identity (individualism, collectivism, Protestant work ethic, ethnic identity) scales tended to correlate with one another $(.23 \leq r \leq .42$ for Blacks, $.19 \leq r \leq .48$ for Whites). We conducted univariate analyses for each subgroup. The closed-ended scales were differentially related to strategies in a manner consistent with the underlying assumptions of the proposed ethnic identity model. Thus, for White students, the number of strategies they described themselves as currently using to approach achievement-related possible selves was predicted by endorsement of individualism $(\beta=.23, p=.07)$, the Protestant work ethic $(\beta=.29, p=.02)$, and balance in achievement-related possible selves $(\beta=.46, p<.001)$.

Conversely, for Black students, the number of strategies they described themselves as currently using to approach achievement-related possible selves was predicted by lower endorsement of individualism $(\beta=-.26, p=.10)$, and higher endorsement of collectivism $(\beta=.24, p=.11)$, and tended to correlate 
positively with ethnic identity ( $\beta=.16, p=.12$ ). Although not significant, the pattern is interesting because it differs markedly from that of the White students. Differences in the correlations between strategies and the independent variables for White and Black students were tested by means of a $z$ test for independent correlations, $z(60,39)=2.37, p<.05$, for individualism, $z(60$, $39)=2.46, p<.05$, for balance in achievement-related possible selves. In addition, whereas strategies for avoiding feared achievement-related possible selves were highly correlated with balance in achievement-related selves for African Americans, the correlation was less robust for Whites, $z(60,39)=2.26$, $p<.05$.

With regard to the hypothesized relationship between strategies to obtain possible selves and components of identity, the number of currently used strategies generated with regard to attaining achievement-related possible selves tended to differ, with Black students describing more strategies than White students, $F(1,103)=2.88, p=.09(M=1.74$ for Blacks, $M=1.44$ for Whites). However, students did not differ in the number of currently used strategies they generated with regard to avoiding failures in their achievement-related possible selves, $F(1,103)$ $<1.0(M=1.13$ for Whites and $M=1.12$ for Blacks $)$.

Although of modest reliability, scale scores suggested that Black and White students differ in a number of correlates of ethnic identity, with Blacks being higher in ethnic identity, $F(1$, $102)=21.40, p<.001(M$ for Blacks $=3.79, M$ for Whites = 3.27 ); and collectivism, $F(1,102)=3.69, p<.05$ ( $M$ for Blacks $=2.99, M$ for Whites $=2.78)$; and Whites were more likely to endorse the Protestant work ethic scale, $F(1,102)=4.46, p<$ .05 ( $M$ for Blacks $=3.21, M$ for Whites $=3.43$ ). However, Blacks and Whites did not differ in level of individualism $(M$ for Blacks $=3.79, M$ for Whites $=3.66), F(1,102)=1.46$, $p>.10$.

Moreover, Blacks and Whites differed in the psychometric structure of the scales. For example, for Whites, two items of the ethnic identity measure that focused on integration-accommodation (e.g., "It is important to me to be familiar with both my own culture and that of larger society") comprised the core elements of the ethnic identity scale in that, when deleted, the scale's reliability dropped to below .4, and they comprised the first factor when the items were factor analyzed, explaining more than $27 \%$ of the variance. For Blacks however, four items focused on a sense of separateness (e.g., "Others are often prejudiced against members of my group") comprised the core elements of the ethnic identity scale as they loaded on the first factor when the ethnic identity items were factor analyzed, explaining $39 \%$ of the variance, and reliability of the scale actually would have improved if the integration-accommodation elements were removed.

This difference in the meaning of the scales was true also for the individualism scale, on which the core items for Whites focused on achievement (e.g., "In order to know who I really am, it is best to look at what I have done and achieved"), whereas the core items for Blacks focused on uniqueness of the self (e.g., "No one else can really know me the way I know myself"). The collectivism and Protestant work ethic scales also showed differential loading of items. To further explore the described differences, we used a Rasch scaling model to estimate item pa- rameters for the Black and White subgroups and to test the hypothesis that there was one latent dimension for each measure for both subgroups (Kleiter \& Hanisch, 1989). To test for differences between subgroups we used a conditional maximum likelihood estimation test. An additional 101 students filled out these scale items to increase the power of this test. Overall, estimates differed significantly for the collectivism scale, $\chi^{2}(10, N$ $=203)=24.51, p<.01$; the individualism scale, $\chi^{2}(8, N=$ $203)=-34.89, p<.001$; the Protestant work ethic scale, $\chi^{2}$ $(10, N=203)=24.37, p<.01$; and the ethnic identity scale, $\chi^{2}(8, N=203)=77.95, p<.001$; emphasizing the need for separate analyses and underscoring the importance of a theory of self-concept in which ethnic identity plays a central role for African Americans even at the college level.

\section{Discussion}

The theoretical model proposed suggests that individualism as a worldview may not be advantageous to African Americans because it focuses on separateness and achievements as the essence of personhood, making one vulnerable to self-blame or depression if one does not achieve (perhaps because of structural limitations) and also reducing one's ability to make sense of the world to the extent to which one is viewed being importantly defined by group membership. The model also posits the higher level of collectivism as a worldview found among African American students. Such a worldview is compatible with the group ties and connectedness to heritage described in the literature. It allows for mobilization of the self to achieve as part of the group rather than alone and separate from it. A connected sense of self may therefore protect the self and allow for development of strategies to attain achievement-related possible selves. In addition, in an environment assumed to be at least somewhat hostile to one's success as an African American, African Americans may focus more on strategies to avoid problems, pitfalls, and failures than members of the majority group. Thus, even among university students, who arguably have "succeeded," a model focused on the worldviews and self-concept of African American youths differs substantially from that focused on White youths.

Findings from this study suggest that Black students differed from White students on the predictors of strategies to obtain achievement-related possible selves as well as their endorsement of ethnic identity and related measures. Moreover, item loadings on the scales suggest that direct comparison between White and Black students may not be possible because these students appear to be making somewhat different sense of the questions on which the scales are based. Thus, among Whites, those who view the self as bounded and defined by its achievements, who view themselves as personally responsible for their own achievements, who conceptualize themselves in the future in terms of academic and work-related achievements to be attained and failures to be avoided, are also more likely to describe a variety of strategies they are currently using to approach their achievement-related possible selves. This study involved university students, all of whom had presumably developed strategies for academic achievement that were at least somewhat helpful. Subsequent studies focused on middle-school youths, who are likely 
to be struggling to develop such successful strategies. In the following studies, we used more direct measures of school performance and focused on the process for African American youths rather than comparing White and Black youths, as our model focuses on the context of African American youths.

\section{Study 2: Gendered African American Identity and School Persistence}

As a preliminary test of the hypothesized components of African American identity and their relationship to coping with school tasks, we explored the impact of identity content and salience on persistence performance in a math task and affective response to the task. Following the model, we hypothesized that the three identity components would predict persistence such that the identity component "achievement as an African American" would have a positive impact on performance of school tasks, particularly when this identity is made salient. When linked with the awareness-of-racism component, the achievement component would have a particularly strong positive relationship with school performance. Youths who conceptualize themselves in terms of achievement as an African American and also are personally aware of the existence of racism and its implications for one's own life will be better equipped to deflect negative feelings about the possibility of success and continue to work on an academic task even when it is difficult. Although the identity components "awareness of racism" and "connectedness-pride in heritage" would relate to self-esteem and enhance the effect of the achievement component, they would not improve persistence if the achievement component were lacking. Each of the identity components would serve a self-protection function such that when made salient, youths high in each of these components would be better able to preserve a positive mood after engaging in a novel and somewhat ambiguous achievement task. Identity would be gendered, with males less likely to view the self as contextualized than females.

\section{Method}

\section{Participants}

The study involved a middle-school sample $(n=146)$ of seventh and eighth grade African American male and female students from an inner city Detroit middle school ( $83 \%$ of whom were receiving free or reduced lunch and were from families who received Aid for Families with Dependent Children payments, or both).

\section{Procedure}

The study took place in school during January-June, 1994. Parents were mailed letters and self-addressed postage paid response postcards to their homes. The purpose of the study was explained, as was its voluntary and anonymous nature. Because the school would use results of the study series as part of its evaluation of possible routes to improve school performance, parents who did not wish to have their child participate were asked to return the postage paid response cards. Somewhat less than $10 \%$ of parents chose not to have their child participate. Youths were told about the purpose of the study and its anonymous and voluntary nature before being individually interviewed by African American university students who had attended area high schools.
The experimental design, in which half of the sample first responded to identity questions and then completed the math task, and the other half of the sample first completed the math task, allowed for exploration of the impact of identity salience-bringing identity to mind as well as identity content-on persistence at the math task.

\section{Measures}

Open-ended identity. Because we could not locate age-appropriate measures of African American identity, we used open-ended probes that we had developed for this study. The probes focused on what it means to a youth to be Black or African American. Interviewers wrote down verbatim responses. Daphna Oyserman and the interviewers read through the interviews and, in a series of meetings, jointly arrived at eight categories of response, listed below. Questionnaires were double coded in group coding sessions, with disagreements discussed until a consensus was reached, and a lexicon for each category was established. Questionnaire responses were coded for the number of nonredundant meaning units focused on each of the eight categories. The eight categories were:

(1) Connectedness-pride in heritage, a sense of connection to one's past and history as well as to one's family, community, and church ( range $=0-4, M=1.44, S D=1.16$ ).

(2) Vision-responsibility - a sense of vision or responsibility to improve the situation of oneself and others, or a focus on increasing equality in human relations ( range $=0-3, M=0.29, S D=0.63$ ).

(3) Racism-particular experiences involving feeling excluded, being stared at, not being served or attended to while in a mall, being tailed or asked to leave by security guards, and being told that one is not liked as a Black ( range $=0-5, M=0.99, S D=1.22$ ).

(4) Everyday behaviors-coping strategies-everyday behaviors engaged in that allow one to cope with the situations described above and make one "feel" Black or African American. These included hanging out with friends, playing sports, dancing, listening to music ( range $=0$ $5, M=0.55, S D=0.95$ ).

(5) Being male-female African American-males and females described gender specific behavior. Females often described limitations and things they could not do because they were female, such as staying home and helping at home versus staying out and playing sports, needing to be sure that "guys know you are the kind of girl who must be respected" versus acting tough. They also described ways of dressing and doing their hair. Males described things about being a male that were easier than being female, often related to hair and personal grooming, specific sports such as basketball that they felt were for males only and made them feel African American (range $=0-5, M=0.85, S D=$ 1.03).

(6) Awareness of problems, limitations-negative experiences associated with being Black (e.g., "living in a war zone," "being part of an endangered species") or risk behaviors associated with being Black (e.g., playing football without pads, smoking, eating fatty foods, not worrying about health and diet (range $=0-6, M=0.84, S D=1.26$ ).

(7) Achievement-attainments-achievement in school, a desire to "be someone" (range $=0-4, M=0.74, S D=1.04$ ).

(8) Disengagement - descriptions of "acting" Black, focusing on dress (e.g., sagging pants, turning cap backward), demeanor (e.g., acting tough, like a gangster), use of slang, or "acting" White, focusing on use of standard English (e.g., proper English, big words) and of school success (e.g., "She acts White but that is okay because she is good in math") (range $0-2, M=1.16, S D=0.90$ ).

Closed-ended identity. We used the 15-item 4-point $(1=$ disagree, 4 = agree) ethnic identity scale initially developed in Study 1 , incorporating items from each of the three proposed content domains (connectedness, awareness of racism, and achievement as an African 
American). We constructed three 5-item subscales, using mean responses to the five connectedness (e.g., "I am glad to be an African American;" $M=3.65, \alpha=.53$ ), awareness-of-racism (e.g., "Some people will treat me differently because I am Black;" $M=2.44, \alpha=.43$ ), and achievement-as-an-African-American (e.g., "It helps my community if I do well in school;" $M=3.40, \alpha=.65$ ) items.

Self-esteem. Self-esteem was measured as the mean of a 6-item 4point scale ( 1 = agree, 4 = disagree) version of Rosenberg's (1965) Self-Esteem scale (e.g., "I am a person of worth). This widely known measure was used in subsequent analyses to explore the variance explained by the African American identity factors not explained by a global self-esteem variable.

Novel math task. A novel math task, not a test of math knowledge, was used. Youths were asked to write down as many ways as they could think of of combining the numbers 2,3 , and 7 to obtain the number 36 . They could add, subtract, multiply, or divide and use each number as many times as they liked. The number of correct responses ranged from 0-12.

Affect. A single item, 5-point Likert-type measure, "How are you feeling right now?" was used to measure affect. Students responded to this item after completing the math task.

\section{Results}

\section{Open-Ended Identity}

Factor analyses, with varimax rotation, of the eight identity categories revealed three factors with eigenvalues at or above 1.00. These categories fit the three hypothesized domains of identity: (a) connectedness with the Black community (Categories 1, 5, and 8), (b) awareness of racism and strategies for coping with it (Categories 3 and 4), and (c) achievement as an African American (Categories 2, 6, and 7).

\section{Gender Differences}

Males and females appeared to differ in the particular content of their responses to the open-ended identity questions. For example, females talked about limitations of being female: "The boys tell us we cannot do things," "The boys call us bitches," and males talked about the advantages of being male: "We can stay out until late." In the achievement category, males talked about "being someone," and girls talked about "graduating high school and getting a job," However, males and females did not differ overall in the categories into which their responses fell, Hotelling's $F(8,122)=1.15, p>.10$; their self-esteem, $F(1$, 129 ) < 1.00 , female $M=1.44, S D=0.38$, male $M=1.39, S D$ $=.38$; or in the extent to which they described themselves in terms of the three African American identity domain factors, Hotelling's $F(3,127)=1.35, p>.10$. Although females tended to be less likely to describe themselves in terms of experiences of racism, $F(1,129)=3.41, p=.07$, than males. Similarly, males and females also did not differ overall in their endorsement of the closed-ended identity subscales, Hotelling's $F$ (3, $127)=1.54, p>.10$, although females tended to endorse the connectedness items more than males, $F(1,129)=2.83, p=$ .09. There was no difference overall between males and females in the number of correct responses to the math problem $(M=$ 2.11 for females, and $M=1.96$ for males; $F<1.0$ ).

\section{Relationships Between the Independent Measures}

The three open-ended identity factors-Connectedness, Racism, and Achievement as an African-American-were not significantly correlated with one another and did not correlate with the closed-ended identity factors. Only the Racism factor was significantly correlated with Rosenberg's self-esteem mea$\operatorname{sure}(r=.17, p<.05)$. Among the closed-ended identity factors, Achievement as an African American significantly correlated with Connectedness $(r=.29, p<.001)$ and with Awareness of Racism $(r=.24, p<.01)$, and Self-Esteem correlated with $\operatorname{Racism}(r=.17, p<.05)$.

\section{Predicting Performance on the Math Task}

The closed-ended identity factors were low in reliability and did not predict performance. We found a complex relationship between identity and performance when the factor scores based on the open-ended measures were used in a hierarchical multiple regression equation, as is described below. A hierarchical multiple regression equation, with identity salience (operationalized as focusing on identity before completion of the math task), self-esteem, and gender entered first, followed by the three open-ended identity factors and then the 6 two-way interaction effects (Identity Salience $x$ each of the three identity factors and each of the pairs of identity factors), and finally the 4 three-way interactions (Identity Salience $\times$ each pair of identity factors and the three identity factors) and 1 four-way interaction (Identity Salience $X$ the three identity factors), was significant, $F(17,127)=2.14, p<.01, R^{2}=.22$. When all the variables had entered the equation, we found significant main effects for self-esteem $(\beta=.18, p=.03)$, connectedness $(\beta=$ $-.24, p=.04)$, and achievement $(\beta=.29, p=.01)$. Significant two-way interaction effects were found for Achievement $\times$ Racism $(\beta=.45, p=.002)$ and Connectedness $\times$ Identity Salience $(\beta=-.23, p=.05)$, with a trend for Achievement $\times$ Identity Salience $(\beta=.19, p=.09)$. Of the three-way interactions, Identity Salience $\times$ Achievement as an African American $\times$ Awareness of Racism was significant $(\beta=-.31, p=.02)$, with a trend for Achievement $\times$ Racism $\times$ Connectedness $(\beta=-.28, p=$ .07 ). Finally, as hypothesized, the four-way interaction of Identity Salience $\times$ Achievement $\times$ Racism $\times$ Connectedness was significant ( $\beta=.28, p=.03$ ). Thus, those high in the achievement and racism components of identity performed better on the math task, especially when identity was made salient. Those high in the connectedness components as well as the achievement and racism components performed better only when identity was made salient, otherwise the connectedness component appeared to dampen performance.

Although gender was not a significant predictor of performance, the model posits that it is significant for the content of identity and the relationship between identity and school performance; therefore, we tested separate regression equations for males and females. For males, the full equation was not significant, $F(16,67)=1.02, p>.10$ and only when main effects alone were considered was there a trend toward significance, $F(5,78)=2.02, p=.08, R^{2}=.11$, with achievement as an African American $(\beta=.22, p=.05)$ and self-esteem $(\beta=.21$, 
$p=.07)$ predicting performance. For females however, the full equation tended toward significance, $F(16,44)=1.77, p=.07$, $R^{2}=.39$. Significant effects were found for achievement as an African American $(\beta=.70, p=.05)$ and two interaction effects: Identity Salience $\times$ Achievement $(\beta=-.60, p=.05)$ and Identity Salience $\times$ Achievement $\times$ Racism $(\beta=-.69, p=.04)$. A trend toward significance was found for the interaction between achievement and racism $(\beta=.74, p=.07)$. Thus, for females, the achievement-as-an-African-American identity component predicted performance, as did the awareness-of-racism component when it occurred in conjunction with the achievement; these effects were heightened when identity was made salient. Our socially contextualized model appears particularly relevant for females, as hypothesized.

\section{Affect}

Neither salience of identity nor gender was significantly related to affect, $F(1,129)<1.0$. However, when the identity factors were entered into the equation they significantly predicted affect overall, $F(4,126)=2.92, p=.02$, and again the achievement-as-an-African-American factor had a positive effect $(\beta=$ $.19, p=.03)$, whereas the connectedness factor $(\beta=-.19, p=$ .03 ) had a negative effect. When the interaction between salience and content of identity factors was entered into the equation, $F(7,123)=4.65, p<.001$, we found that, when made salient, the achievement-as-an-African-American factor had a particularly positive impact on affect after the math task $(\beta=$ $.34, p=.00)$, whereas the connectedness factor had a particularly negative impact when made salient $(\beta=-.28, p=.02)$; when made salient, the racism factor tended to have a positive effect $(\beta=.19, p=.07)$. As a whole, then, the African American identity factors tended to preserve positive affect even after the slight threat of the math task.

\section{Discussion}

Whereas the open-ended identity questions elicited responses focused on the youths' sense of themselves in their everyday lives, the closed-ended questions seemed to focus youths more on their more general attitudes and beliefs about the world. That awareness of racism correlated with self-esteem seems to suggest that recognizing racism either in one's own everyday life or as a general force in society preserves and protects one's sense of personal worth, as suggested in the theoretical model. The lack of correlation between the open- and closed-ended identity measures suggests that they are not tapping the same underlying dimensions-the open-ended measures seem more focused on the immediate self-concerns of the youths, and the closed-ended measures may more aptly describe general value statements or worldviews.

In terms of school performance, we found that salience of identity does not predict performance when content of identity is not taken into account and that general self-esteem has a positive effect on performance. The impact of the achievement component of identity follows our model in that youths with this conceptualization perform better. As hypothesized, alone, connectedness to the group does not have a positive effect on achievement. These findings are similar to those described by Steele (1988), who found that when African Americans have this social identity made salient by checking off their ethnicity before beginning a Scholastic Aptitude Test-like achievement test, they perform worse than when this social identity is not made salient. Presumably, reminding students of their ethnic identity makes salient the "connectedness" component of identity and structural limitations faced by the group, perhaps discouraging effort or making salient non-achievement-related aspects of the self.

The complex impact of awareness of racism suggests that it may fulfill an important self-protecting function and therefore promote self-esteem. Yet alone it does not promote continued persistence, perhaps because it provides a rationale for failure. It is in conjunction with the achievement factor, especially when identity is made salient, that the awareness-of-racism factor is harnessed in the service of persistence. Thus it appears that the open-ended identity variables do indeed predict school persistence in a manner commensurate with the proposed model. Findings are strongest for females.

\section{Study 3: Exploring the Contextual Determinants of Gendered Identity}

Study 2 suggested differences in the impact of African American identity on behavior for males and females. Following the socially contextualized model, we hypothesized that youths' construal of possibilities for the self would depend on the context of this construal. We assumed that differences between males and females found in Study 2 are rooted in divergent ways of conceptualizing what matters in the social context. In Study 3 we explored possible differences in the social contextual impact on youths' self-construals. Thus, when focused on similar others who are successful in school, youths might be able to visualize more possibilities for success than when focused on similar others who are doing poorly or even failing in school. We hypothesized that this effect would be enhanced when youths were asked explicitly to focus on similarities between the self and successful others or on differences between the self and failing others versus situations in which they were asked to focus on similarities between the self and failing others or on differences between the self and successful others. Following the model, we hypothesized that this effect would be gendered in that it would be stronger for females than for males.

\section{Method}

\section{Participants}

A subset of 55 male and female students included in Study 2 also received Study 3 materials at the conclusion of Study 2 .

\section{Procedure and Measures}

After being thanked for participating in the study, a subset of students was asked to participate in an additional study. All students requested to participate agreed to do so. Approximately one-fifth of the students was then asked a single question: "How likely is it that you will be suc- 
cessful in school next year?" A second group of students (approximately two-fifths) was first told

We are particularly interested in learning about students who do well in school. Take a moment to think of someone you know who is doing well or has done quite well in school. Can you describe that person to me?

The third group of students (approximately two-fifths) was first told

We are particularly interested in students who are doing badly in school and may even fail. Take a moment to think of someone you know who is doing badly in school, someone who might fail or has failed. Can you describe that person to me?

Thus, for one group of students, no social context had been made salient before asking about subjective assessment of likelihood of success in school in the coming year. Half of the remaining students were focused on success, and half were focused on failure. In addition, half of the students in each social context group were asked to describe ways in which they were similar to the person they had just described, and half were asked to describe ways in which they differed from the person they had just described: Salient social context was thus success or failure, and one's own similarities or differences to the salient social context also were brought to mind.

The four experimental conditions, then, were successful other-similar, failure other-different, successful other-different, failure othersimilar. In a fifth, control condition, no context was presented. The dependent measure was a single-item question: "How successful do you expect to be in school next year?" Across conditions, the average response $(M=1.62 ; 1=$ very likely to do well, $4=$ very unlikely to do well $)$ suggested that youths were highly optimistic about their future.

\section{Results}

There was a trend for context and gender to affect expectations across students, $F(5,45)=2.19, p=.07$, as well as a Context $\times$ Gender interaction effect, $F(4,45)=2.34, p=.08$. Overall, the main and interaction effects explain a significant amount in variance in expectations, $F(9,45)=2.10, p=.04$, $R^{2}=.17$, as can be seen in Figure 2. Males tend to view the likelihood of success in school next year as higher when they think about the likelihood of success after thinking about similar others and their success, overall. This tends to reduce subjective likelihood of success. This dampening effect of social context is particularly true for females.

Though only marginally significant, perhaps because of small sample size, subgroup analyses suggest that the way that social context influences possible selves differs for males and females, as can be seen in Figure 2. Specifically, males who have brought to mind similarities between the self and a similar other who is failing, or who have brought to mind differences between the self and a similar other who is succeeding in school, voiced more pessimism about their future than males in the other two context conditions (similarities between the self and a successful other and differences between the self and a failing other, $F[4,19]=2.33, p=.09$ ). The social context effect for females, on the other hand, comes from the opposite source. Females are more pessimistic about their chances for future success when they have tried to bring to mind the ways they are similar to someone they know who is doing well and when they have tried to bring to mind the ways they are different from someone they know who is doing poorly, as compared with bringing to mind ways they are different from someone who is doing well or ways they are similar to someone who is doing poorly, $F(4,26)=$ $2.31, p=.08$. In these latter conditions, females are as optimistic as in the no-context condition.

\section{Discussion}

As suggested in the model, social context and gender appear to influence youths' beliefs about what is possible for them in the future. A possible interpretation is that African American males, while still in middle school, scan the social environment for information about the self in a manner that protects them from negative feedback about what is possible for the self. Only when their attention is drawn to similarities between the self and others who are failing, or differences between the self and others who are succeeding, does the individual sense a restriction of possibility. Conversely, same-grade-level African American females may scan the social environment quite differently. Already more aware of the potential for restricted opportunity, girls may be scanning their social environment and asking themselves " $A m$ I similar to others I know who are doing well?" and " $A m$ I different from others I know who are failing?" Lack of certainty may result in a further decrease in one's own sense of one's possibilities of succeeding in school. Alternatively, males may choose more similar others as models of success and more divergent others as models of failure than females such that the task of comparing the self to these others may have in fact been different for males and females. Finally, the differences found may be rooted in the greater interdependence of females and the higher instrumentality or individualism of males. Thus, male responses appear to follow the attributional biases described by Markus and Kitayama (1991) in their discussion of individualism. To the extent that males may develop a more bounded sense of self while females develop a more interdependent and relational sense of self, then for males-being able to visualize the self in action-moving toward future goals may be a more powerful predictor of current performance.

\section{Study 4: Balance in Possible Selves, Gender, and School Performance}

In Study 4 we explored further the relationship between identity and school performance by looking more specifically at balance in possible selves as a predictor of school performance. We postulated that balance in expected and to-be-avoided achievement-related possible selves would provide a framework for increased school persistence. Balanced achievement-related possible selves would focus youths on school and make them less susceptible to moment-to-moment fluctuations in their social context.

\section{Method}

\section{Participants}

This study was undertaken at a middle school involving students not previously interviewed. The sample included the 55 eighth grade 

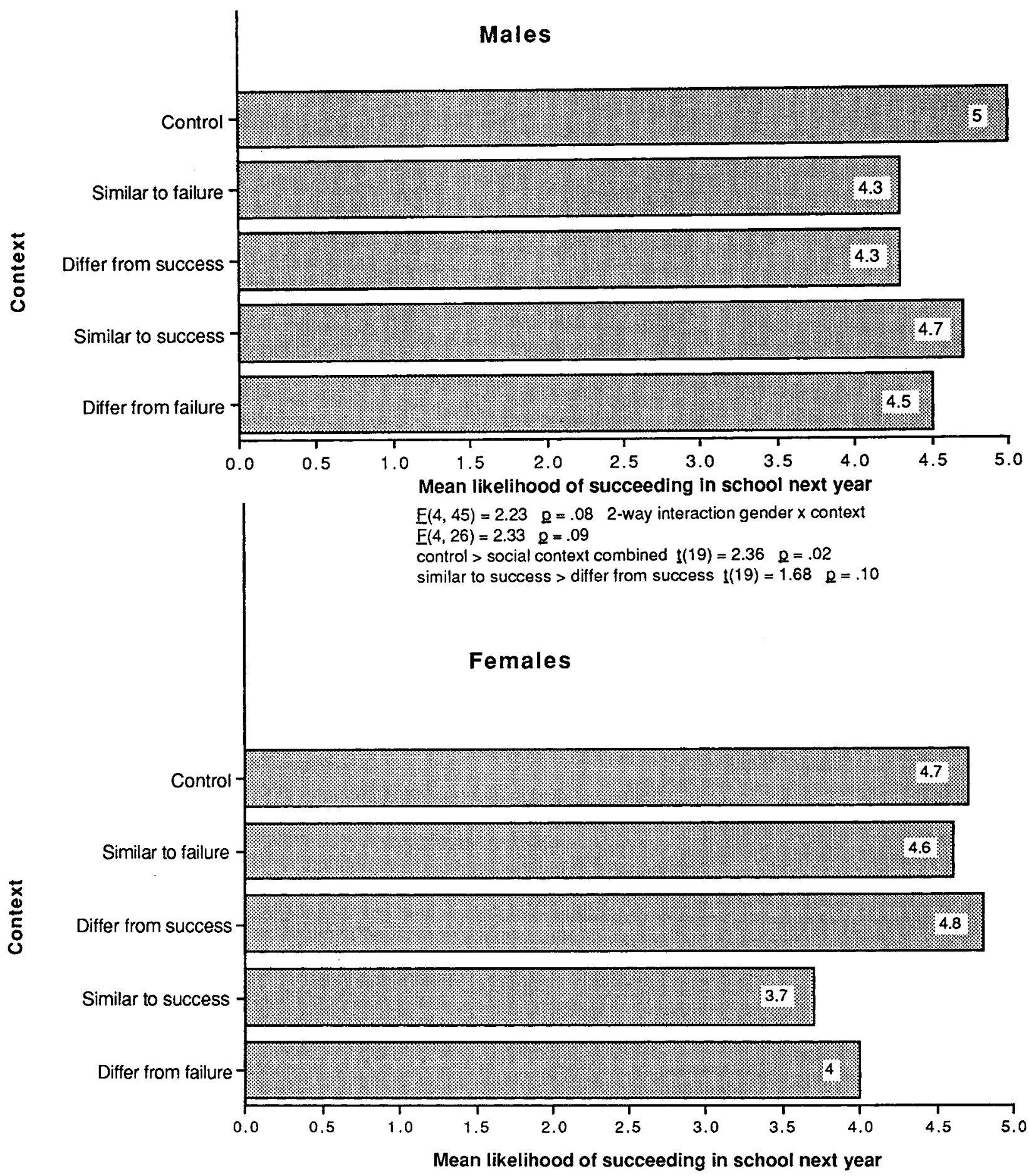

$E(4,26)=2.31 \quad \mathrm{~g}=.08$

similar to failure, differ from success $>$ similar to success, differ from failure $\mathrm{t}(26)=-2.59 \mathrm{~g}=.01$

differ from success $>$ similar to success $\quad f(26)=-2.20 \quad \mathrm{Q}=.03$

Figure 2. The gendered impact of social context on possible selves. 
African American male and female students present in three of the schools' 16 classrooms on a given day in May, 1994. Data from the 5 White students in these classrooms were excluded from analyses: an additional 15 students listed on the school roster were absent or on field trips that day.

\section{Procedure}

The procedure involved classroom administration of individual study materials by Daphna Oyserman and Larry Gant. Teachers were present in the classroom but were given a questionnaire of their own to fill out, as is described below.

\section{Measures}

School performance was measured with four variables: mean cumulative grade point average (GPA) for the first three quarters of the school year (4th quarter data were not yet available), California Achievement Test (CAT) Math subtest scores, CAT English subtest scores, a 5-item persistence scale devised for the study, including teacher and student perspectives on two items ("How important is it to this student/you to do all of your homework?" and "How hard does this student/do you try to do well in school?") and an item asked only of students ("How important is it to you to ask questions when you do not understand something in class?"). The five items correlated at $.19 \leq r \leq .86$. Although all students and teachers responded to the persistence subscale, data were available from records for only 28 students on the CAT and only 44 students for GPA.

Regarding balance in achievement-related possible selves, youths varied widely in the extent to which they generated balanced possible selves for the coming year (range: $0-4$, with 28 youths generating no balanced possible selves and the other 27 youths averaging 1.4 balanced possible selves).

\section{Results}

The four achievement measures correlated at $.33 \leq r \leq .76$. Overall, males and females differed in balance in possible selves, with females averaging 1.33 and males averaging $0.42, F(1,48)$ $=10.86, p<.001$. Balance in possible selves predicted effort invested in school as measured by student and teacher perspective $(M$ effort $=2.10, S D=0.76 ; M$ balance $=0.90, S D=$ 1.08) $F(1,46)=6.06, p=.02, R=.34$. Discriminant function analysis suggests that, considered jointly, males and females differed in balance and persistence, $F(2,45)=9.20, p<.001$, $R^{2}=.29$. Gender differences are apparent in that balance tended to be related to effort for males, $F(1,22)=2.80, p=$ $.10, R=.34$, and not for females, $F(1,22)<1.0, p>.10$. To explore this interaction effect, we used a multiple regression equation that included gender and its interaction with balance, $F(3,44)=5.91, p=.002, R=.54$. There was a significant contribution of gender $(\beta=.39, p=.008)$. There was a trend toward a Gender $\times$ Balance interaction effect $(\beta=-.26, p=$ .11). African American females view themselves and are viewed by teachers as trying harder and viewing homework as more important and have more balance in possible selves. Even though they are lower overall in balance in possible selves, the Gender $\times$ Balance interaction effect suggests that the relationship between balance and persistence is stronger for males.

To look at the relationship between balance and our achievement measures of effort, we used the subset of 28 students for whom CAT data were available. Using the same multiple regression procedure used above, we found that the overall $R$ was the same as when the more subjective measure of school effort was used. Thus, taken together, balance and possible selves predict performance for those youths with English CAT scores on record, $R=.54, F(3,23)=3.23, p=.04$. ( $M$ CAT English $=$ 23.75, $S D=16: 09 ; M$ balance $=1.07, S D=1.15$.)

Gender did not have a main effect on CAT English scores ( $\beta$ $=.20, p>.10$ ). There was a trend for more balance to be related to higher CAT English scores $(\beta=.38, p=.07)$, and the interaction between gender and balance was significant $(\beta=.54, p=$ .03 ). As with the effort measure, balance is especially related to enhanced CAT English performance for males.

For youths with Math CAT test scores on record, balance and gender predicted performance, $R=.60, F(3,24)=4.51, p=$ .01 ( $M$ CAT Math $=25.39, S D=14.68, n=28)$. Specifically, balance predicts $(\beta=.53, p=.005)$, but gender does not $(\beta=$ $-.14, p>.10$ ), and the interaction between balance and gender was not significant $(\beta=.06, p>.10)$. Whether male or female, youths with more balanced possible selves scored better on the Math test.

Finally, for the 44 youths with GPAs on record, balance and gender predicted performance, $R=.55, F(3,40)=5.77, p=$ $.002(M \mathrm{GPA}=2.37, S D=.60 ; M$ balance $=0.91, S D=1.10)$. As found previously, gender alone was not a significant predictor of achievement $(\beta=.02, p \geq .10)$; balance predicted performance $(\beta=.42, p=.01)$, as did the interaction between gender and balance $(\beta=.42, p=.01)$. As before, the effect of balance was enhanced for males.

\section{Discussion}

As was found in previous work with high school students (e.g., Oyserman \& Markus, 1990b), balance in possible selves has a positive effect on school persistence. The effect appears to be considerably stronger for males than for females. The effects of balance were consistent across subjective as well as objective measures of school persistence and achievement. The findings for males are of particular note for two reasons. Even though, as a group, males have less balance in achievement-related possible selves, males who have balanced possible selves tend to perform much better in school. Thus, to the extent that one can change the way males conceptualize what is possible for them in the future, an enhancement of school performance and persistence may follow. Males are particularly at risk for dropping out and delinquent involvement, and they seem less likely to conceptualize themselves in the contextualized manner that was the focus of Study 3.

\section{General Discussion}

Our theoretical model posits that gendered African American identity schemas are central for school persistence. These schemas are viewed as the scaffolding within which balanced possible selves in the achievement domain are generated and strategies for their attainment sketched out. Gendered African American identity schemas, as schemas, are likely to also have a more direct impact on one's subjective sense of what is probable and 
plausible for the self (e.g., Markus, 1977). As schemas, these gendered identities are the lenses or prisms through which adolescents make sense of the world. One's everyday social contexts are scanned within the vocabulary of one's emerging identity. Current action is scripted by what is viewed as a good, important, and plausible outcome within one's context.

In the four studies we conducted, we found initial evidence for an African American identity schema. As expected, African American and White students differed in the way they interpret and use scales describing the self. In Study 1 we found that African Americans were higher in collectivism and strategies for attaining achievement oriented possible selves. These strategies were differentially predicted for White and African American students. This initial evidence for difference between White and African American students formed a baseline from which we continued to explore issues relevant to African American students.

We found predicted self-conceptualization patterns as early as middle school. African American students conceptualized themselves in ways compatible with our theoretical model, and these conceptualizations appear to have implications for everyday behavior. Thus, students high in achievement as an African American stayed on task longer, particularly if their identity as an African American also included awareness of racism, and if identity was made salient. Furthermore, youths high in all three African American identity schema components felt better after the math task than other youths, suggesting that African American identity thus constructed does have a self-protective function as hypothesized. Overall, effects for our socially contextualized model were stronger for females. It may be that construction of a social or relational identity is less effortful and more congruent with gender role identity for females than for males. For males, socialization may focus on construction of a bounded, task-oriented or instrumentally oriented self. In this way socially contextualized selves may not be as central in determining behaviors for males as for females.

When we explored gender differences in the impact of social context on identity, we found that females and males responded differently. Focusing on similarities to successful others was productive for males and counterproductive for females in that subjective probability of school success was enhanced for males and dampened for females. At least two plausible explanations for this differential impact should be objects of further study. First, males may respond to thinking of their successful role model by "basking in the reflected glory" (e.g., Gollwitzer \& Wicklund, 1985 ) rather than by attempting to figure out how to be that way: perhaps males and females scan the environment differently. Females may be more likely to look at real and apparent obstacles, asking themselves whether they can actually attain the successes of their role model or avoid the failures of their "anti" model (the failure condition). In addition, males may view highly similar others as role models, whereas females may aspire toward successes and achievements of others who are quite different from the self, objectively or subjectively.

Gender differences also were apparent in our examination of possible selves. Though females are more likely to have balanced possible selves in the achievement domain, having these selves is especially advantageous for males. These findings and the gendered differences in the impact of gendered African American identity on performance highlight the importance of studying not only possible differences between males and females on the content of identity but also differences in the impact of identity on behavior. For females, viewing achievement as part of a socially contexualized identity improves performance. For males it is the ability to visualize the self as achieving or failing to achieve that is particularly motivating.

The particular self-conceptualizations constructed, and their use in the pursuit of academic goals, may be especially critical within social contexts that do not afford numerous or redundant opportunities for smooth transition into adulthood. When poverty and unemployment are chronically high, the perceived connection between one's current efforts to do well in school and one's future possibilities as an adult may be severely attenuated. In addition, it may be quite difficult to develop concrete instantiations or visions of the self succeeding in the world of school and work. Lack of success or failure in school may not be viewed as self-defining to the extent that it is not viewed as linked to one's future chances as an adult.

We have suggested that a sense of self develops as people find or create answers to the questions of "Who am I?" and "Where do I belong?" The psychological literature often focuses attention on the way in which people actively and deliberately pursue and custom-craft answers to these questions. Thus, philosopher R. L. Taylor wrote

To know who you are is to be oriented in moral space, a space in which arise about what is good or bad, what is worth doing and what is not, what has meaning and importance for you, and what is trivial and secondary. (1989, p. 28 , italics added)

Yet in spite of our assumptions about the individuality and idiosyncratic nature of the self, some important aspects of the self are a consequence of one's relative positioning in sociopolitical and historical context; they are developed interpersonally and consensually. These socially scaffolded identities infuse content, color meaning, and structure possibilities yet are personalized and feel uniquely self-defining to the individual.

We have argued that these social representations of what it means to be a good, moral or worthwhile self may be particularly powerful for individuals who are members of socially stigmatized groups, groups who must struggle to create a positive sense of what is possible for the self within constraining or actively limiting contexts in which certain identities may be foisted on the self and other identities co-opted because they are viewed as defining out-group members.

Thus, African American youths must create a positive sense of themselves and what is possible for themselves both as African Americans generally and as African American students particularly within social contexts that may define school success as "acting White" and thus perhaps not "Black" (e.g., Ogbu, 1991). Similarly, working-class youths must create a positive sense of themselves and what is possible for them in an economically strained social context in which unemployment is becoming increasingly normative and school success may be viewed as defining a middle-class out-group.

Further study must focus on the specific ways in which social context makes a difference in the process of identity construc- 
tion for adolescents. In the current research, middle-school youths lived in urban contexts that were primarily African American, and they lived in neighborhoods and communities lacking material resources. In the city of Detroit, $82 \%$ of youths aged 18 and under are African American, and $47 \%$ of these youths are living in poverty, a rate higher than any other large U.S. city (Neithercut, 1993). Although roughly $53 \%$ of youths graduate Detroit high schools on time, almost half do not. Rates of crime and other victimization also are high and, since 1986, between 291 and 365 youths aged 16 and under were shot each year in the city (Neithercut, 1993).

Further study must begin to tease out the extent to which it is this juxtaposition of an African American context and limited resources that potentiates African American identity schemas. Thus, it may be that middle-class youths growing up with more "cultural capital" are able to negotiate a sense of self that appears acontextualized in that the constraints and limitations of one's contexts do not need to be spelled out and made sense of within one's self-concept. Alternatively, the task of identity construction may differ for youths growing up in less ethnically homogeneous circumstances. Thus, youths in schools, neighborhoods, and communities that are racially mixed or racially balanced may negotiate identities under different circumstances than youths in predominantly African American contexts. To the extent that youths interact with one another and race is not viewed as a boundary, economic and gender differences may serve similar limiting functions that must be dealt with or will constrain the self constructed (e.g., Haw, 1991).

The triadic identity structure we propose, in which the individual must find some way of connecting the self to the group, a path toward academic achievement as a group member, and a way of making sense of stereotypes and the structural limitations imposed by one's group membership, may well be generalizable beyond African American identity and provide a framework for study of identity development that takes into account the experiences of youths who must struggle to find a means of conceptualizing plausible paths toward academic success. Thus, when social context is limiting and group membership functions to subtly or not so subtly shape the selves one "tries on" in the process of adolescent development, we propose that by conceptualizing oneself as a group member, becoming aware of stereotypes and limitations, and developing a perspective of oneself as succeeding as a group member, allows a way out. Otherwise, academic success may be viewed as co-opted by the White middle class and, in some domains, by male or female members of our society.

\section{References}

Akbar, N. (1991). Visions for Black men. Nashville, TN: WinstonDerek.

Allen, W. R., \& Farley, R. (1985). The shift of social and economic tides of Black America. Annual Review of Sociology, 12, 277-306.

Anderson, L. P. (1991). Acculturative stress: A theory of relevance to Black Americans. Clinical Psychology Review, 11, 685-702.

Asante, M. K. (1987). The Afrocentric idea. Philadelphia: Temple University Press.

Asante, M. K. (1988). Afrocentricity. Trenton, NJ: African World Press. Azibo, D. A. Y. (1991). An empirical test of the fundamental postulates of an African personality metatheory. The Western Journal of Black Studies, 15, 183-195.

Bandura, A. (1986). Social foundations of thought and action. Englewood Cliffs, NJ: Prentice Hall.

Bernstein, B. (1991). Central issue importance as a function of gender and ethnicity. Currents in Psychology, 10, 241-252.

Bowman, P., \& Howard, C. ( 1985). Race-related socialization, motivation, and academic achievement: A study of black youths in threegeneration families. Journal of the American Academy of Child Psychiatry, 24(2), 134-141.

Bowman, P. J. (1990). Coping with provider role strain: Adaptive cultural resources among Black husband-fathers. Journal of Black Psychology, 16, 1-21.

Bowman, P. J. (1991). Work life. In J. S. Jackson (Ed.), Life in Black America (pp. 124-155). Newbury Park, CA: Sage.

Broman, C. L., Jackson, J. S., \& Neighbors, H. W. (1989). Sociocultural context and racial group identification among Black adults. Revue Internationale de Psychologie Sociale, 2, 367-378.

Brown, P.M. (1990). Biracial identity and social marginality. Child and Adolescent Social Work, 7, 319-337.

Brown-Collins, A. (1993). Perspectives on images of African-American women. Symposium presented at the 101st Annual Convention of the American Psychological Association, Toronto, Ontario, Canada.

Cantor, N., Norem, J. K., Niedenthal, P. M., Langston, C. A., \& Brower, A. (1987). Life tasks, self-concept ideals, and cognitive strategies in a life transition. Journal of Personality and Social Psychology, 53, 1178-1191.

Cantor, N., \& Zirkel, S. (1990). Personality, cognition, and purposive behavior. In L. A. Pervin (Ed.), Handbook of personality theory and research (pp. 135-164). New York: Guilford Press.

Carter, R. T. (1991). Racial identity attitudes and psychological functioning. Journal of Multicultural Counseling and Development, 19, 105-114.

Cernkovich, S. A., \& Giordano, P. C. (1987). Family relationships and delinquency. Criminology, 25, 295-319.

Cernkovich, S. A., \& Giordano, P. C. (1992). School bonding, race and delinquency. Criminology, 30, 261-291.

Chestang, L. (1984). Racial and personal identity in the Black experience. In B. White (Ed.), Color in a White society (pp. 1-18). Silver Spring, MD: National Association of Social Workers.

Corley, C. J., Cernkovich, S., \& Giordano, P. (1989). Sex and the likelihood of sanction. The Journal of Criminal Law and Criminology, 80 , $540-556$

Crane, J. (1991). Effects of neighborhoods on dropping out of school and teenage childbearing. In C. Jencks \& P. E. Peterson (Eds.), The urban underclass (pp. 299-320). Washington, DC: Brookings.

Crocker, J., \& Major, B. (1989). Social stigma and self esteem: The selfprotective properties of stigma. Psychological Review, 96, 608-630.

Cross, W. (1991). Shades of black. Philadelphia: Temple University Press.

Csikszentmihalyi, M., \& Larson, R. (1984). Being adolescent: Conflict and growth in the teenage years. New York: Basic Books.

Curry, C., Trew, K., Turner, I., \& Hunter, J. (1994). The effect of life domains on girls' possible selves. Adolescence, 29, 133-150.

Damon, W., \& Hart, D. (1986). Stability and change in children's self understanding. Social Cognition, 4, 102-118.

Demo, D. H., \& Hughes, M. (1990). Socialization and racial identity among Black Americans. Social Psychology Quarterly, 53, 364-374.

Elliott, D. S., Huizinga, D., \& Morse, B. (1988). A career analysis of serious violent offenders. In I. Schwart (Ed.), Violent Juvenile Crime: What do we know and what can we do about it? (pp. 23-34). Ann Arbor, MI: Center for the Study of Youth Policy. 
Fiske, A. P. (1990). Structures of social life: The four elementary forms of human relations. New York: Free Press.

Fordham, S. (1988). Racelessness as a factor in Black students' school success: Pragmatic strategy or pyrrhic victory? Harvard Educational Review, 58, 54-84.

Freedman-Doan, C., Arbreton, A., Harold, R., \& Eccles, J. (1993). Looking forward to adolescence: mothers' and fathers' expectations for effective and behavioral change. Journal of Early Adolescence.

Gecas, V. (1989). The social psychology of self-efficacy. Annual Review of Sociology, 15, 291-316.

Gibbs, J. T., \& Hines, A. (1989). Factors related to sex differences in suicidal behavior among Black youth. Journal of Adolescent Research, 4, 152-172.

Gibson, M., \& Ogbu, J. (1991). Minority status and schooling. New York: Garland.

Giordano, P. (1991). Black identity scale. Unpublished manuscript, Ohio University, Bowling Green.

Giordano, P., Cernkovich, S., \& DeMaris, A. (1993). The family and peer relations of black adolescents. Journal of Marriage and the Family, 55, 277-287.

Giorgi, L., \& Marsh, M. (1990). The Protestant work ethic as a cultural phenomenon. European Journal of Social Psychology, 20, 499-517.

Gollwitzer, P.M., \& Wicklund, R.A. (1985). The pursuit of self-defining goals. In J. Kuhn \& J. Beckmann (Eds.), Action Control: From Cognition to Behovior. New York: Springer-Verlag.

Hare, B. R. (Ed.). (1988). Black youth at risk. In The state of Black America 1988 (pp. 81-93). Washington, DC: National Urban League.

Hart, D., \& Damon, W. (1986). Developmental trends in self understanding. Social Cognition, 4, 388-407.

Harter, S. (1990). Developmental differences in the nature of self understanding. Cognitive Therapy and Research, 14, 113-142.

Harter, S. (1992). Visions of the self: Beyond the me in the mirror. Nebraska Symposium on Motivation (Vol. 40, pp. 99-144). Lincoln: University of Nebraska Press.

Harter, S., Marold, D., \& Whitesell, N. (1992). Model of psychosocial risk factors leading to suicidal ideation in young adults. Development and Psychopathology, 4, 167-188.

Haw, K., (1991). Interactions of gender and race-A problem for teachers? A review of the emerging literature. Educational Research, $33,12-21$.

Henggeler, S. W. (1991). Multidimensional causal models of delinquent behavior and their implications for treatment. In R. Cohen \& A. Siegel (Eds.), Context and development (pp. 211-231). Hillsdale, NJ: Erlbaum.

Herring, C., \& Wilson-Sadberry, K. (1993). Preference or necessity? Changing work roles of Black and White women 1973-1990. Journal of Marriage and the Family, 55, 314-325.

Higginbotham, E., \& Weber, L. (1992). Moving up with kin and community: Upward social mobility for Black and White women. Gender and Society, 6, 417-440.

Higgins, E. T., Roney, C. J. R., Crowe, E., \& Hymes, C. (1994). Ideal versus ought predilections for approach and avoidance: Distinct selfregulatory systems. Journal of Personality and Social Psychology, 66, 276-286.

Hughes, M., \& Demo, D. H. (1989). Self-perceptions of Black Americans: Self-esteem and personal efficacy. American Journal of Sociology, 95, 132-159.

Hunter, A., \& Davis, J. (1992). Constructing gender: An exploration of Afro-American men's conceptualizations of manhood. Gender and Society, 6, 464-479.

Jackson, J., McCullough, W., \& Gurin, G. (1988). Family, socialization environment, and identity development in Black Americans. In $\mathbf{H}$.
McAdoo (Ed.), Black families (2nd ed., pp. 242-256). Newbury Park, CA: Sage.

Jackson, J. S. (Ed.). (1991). Life in Black America. Newbury Park, CA: Sage.

Jessor, R., Donovan, J. E., \& Costa, F. M. (1992). Beyond adolescence. New York: Cambridge University Press.

Katz, I., \& Hass, R. G. ( 1988). Racial ambivalence and American value conflict. Journal of Personality and Social Psychology, 55, 893-905.

Kirschenman, J., \& Neckerman, K. M. (1991). "We'd love to hire them, but...": The meaning of race for employers. In C. Jencks \& P. E. Peterson (Eds.), The urban underclass (pp. 203-232). Washington, DC: Brookings.

Kleiter, E., \& Hanisch, G. (1989). GUTRA 2 (Basic version). Vienna, Austria: Public Domain Software.

Lamont, M., \& Lareau, A. (1988). Cultural capital. Sociological Theory, $6,153-168$.

Levin, J., \& Taylor, R. (1993). Gender and age differences in religiosity among Black Americans. The Gerontologist, 33, 16-23.

Littlejohn-Blake, S., \& Darling, C. (1993). Understanding the strengths of African American families. Journal of Black Studies, 23, 460-471.

Loeber, R., Wung, P., Keenan, K., Giroux, B., Stouthamer-Loeber, M., Van Kammen, W. B., \& Maughan, B. (1993). Developmental pathways in disruptive child behavior. Development and Psychopathology, $5,103-133$

Loring, M., \& Powell, B. (1988). Gender, race, and DSM-III: A study of the objectivity of psychiatric diagnostic behavior. Journal of Health and Social Behavior, 29, 1-22.

Markus, H. (1977). Self-schemata and processing information about the self. Journal of Personality and Social Psychology, 35, 63-78.

Markus, H., Cross, S., \& Wurf, E. (1990). The role of the self-system in competence. In R. J. Sternberg \& J. E. J. Kolligian (Eds.), Competence considered (pp. 205-225). New Haven, CT: Yale University Press.

Markus, H., \& Oyserman, D. (1989). Gender and thought: The role of the self-concept. In M. Crawford \& M. Gentry (Eds.), Gender and thought: Psychological perspectives (pp. 100-105). New York: Springer-Verlag.

Markus, H., \& Wurf, E. ( 1987). The dynamic self-concept. Annual Review of Psychology, 38, 299-337.

Martinez, R., \& Dukes, R. L. (1991) . Gender differences in self-esteem. Youth and Society, 22, 318-338.

McAdoo, H. P. (Ed.). (1988). Black families (2nd ed.). Newbury Park, CA: Sage.

McAdoo, J. (1991). The roles of Black fathers in the socialization of Black children. In H. McAdoo (Ed.), Black families (pp. 257-269). Newbury Park, CA: Sage.

McCombs, H. G. (1985). Black self-concept. International Journal of Intercultural Relations, 9, 1-18.

Moretti, M., \& Higgins, E. T. (1990). Relating self-discrepancy to selfesteem. Journal of Experimental Social Psychology, 26, 108-123.

Neithercut, M. E. (1993). Status of Detroit area youth. Detroit, MI: Center for Urban Studies, Wayne State University.

Nobles, W. W. (1988). African-American family life. In H. P. McAdoo (Ed.), Black families (2nd ed., pp. 44-53). Newbury Park, CA: Sage.

Oakes, P. J., \& Turner, J. C. (1990). Is limited information processing capacity the cause of social stereotyping? European Review of Social Psychology, 1, 111-135.

Ogbu, J. U. ( 1991). Minority coping responses and school experience. The Journal of Psychohistory, 18, 433-456.

Oyserman, D. (1993). The lens of personhood: Viewing the self, others, and conflict in a multicuitural society. Journal of Personality and Social Psychology, 65, 993-1009. 
Oyserman, D., \& Markus, H. R. (1990a). Possible selves and delinquency. Journal of Personality and Social Psychology, 59, 112-125.

Oyserman, D., \& Markus, H. R. (1990b). Possible selves in balance: Implications for delinquency. Journal of Social Issues, 46, 141-157.

Oyserman, D., \& Markus, H. (1993). The sociocultural self. In J. Suls \& A. G. Greenwald (Eds.), Psychological perspectives on the self (Vol. 4, pp. 187-220). Hillsdale, NJ: Erlbaum.

Oyserman, D., \& Markus, H. R. (in press). Self as social representation. In S. Moscovici \& U. Flick (Eds.), Psychology of the social. Berlin: Rowohlt Taschenbuch Verlag GMbH.

Oyserman, D., \& Saltz, E. (1993). Competence, delinquency, and attempts to attain possible selves. Journal of Personality and Social Psychology, 65, 360-374.

Parham, T. A. (1989). Cycles of psychological Nigrescence. The Counseling Psychologist, 17, 187-226.

Phinney, J. S. (1992). The multigroup ethnic identity measure. Journal of Adolescent Research, 7, 156-176.

Porter, J. R., \& Washington, R. E. (1989). Developments in research on Black identity and self-esteem: 1979-1988. Revue Internationale de Psychologie Sociale, 2, 339-353.

Robinson, T., \& Ward, J. V. (1991). A belief in self far greater than anyone's disbelief. Women and Therapy, 11, 87-103.

Rotheram-Borus, M. J. (1990). Adolescents' reference-group choices, self-esteem, and adjustment. Journal of Personality and Social Psychology, 59, 1075-1081.

Sanders Thompson, V. L. (1991). A multidimensional approach to the assessment of African American racial identification. The Western Journal of Black Studies, 15, 154-158.

Showers, C. (1992a). Compartmentalization of positive and negative self-knowledge: Keeping bad apples out of the bunch. Journal of Personality and Social Psychology, 62, 1036-1049.

Showers, C. (1992b). Evaluatively integrative thinking about characteristics of the self. Personality and Social Psychology Bulletin, 18, 719 729.

Shweder, R. A. (1991). Thinking through cultures: Expeditions in cultural psychology. Cambridge, MA: Harvard University Press.

Simmons, R., Switzer, G., \& Zhou, Y. (1993). Racial, school, and family context among adolescents. Paper presented at the 101st Annual Convention of the American Psychological Association, Toronto, Ontario, Canada.

Solorzano, D. (1992). An exploratory analysis of the effects of race, class, and gender on student and parent mobility aspirations. Journal of Negro Education, 61, 30-44.

Spencer, S. J., \& Steele, C. M. (1992). The effect of stereotype vulnera- bility on women's math performance. Paper presented at the 100th Annual Convention of the American Psychological Association, Washington, DC.

Steele, C. (1988). The psychology of self-affirmation. Advances in Experimental Social Psychology, 21, 261-302.

Strauman, T., \& Higgins, E. T. (1987). Automatic activation of selfdiscrepancies and emotional syndromes. Journal of Personality and Social Psychology, 53, 1004-1014.

Stryker, S. (1987). Identity theory: Developments and extensions. In K. Yardley \& T. Honess (Eds.), Self and identity: Psychosocial perspectives ( pp. 88-103). Chichester, England: Wiley.

Taylor, D. M., \& Dube, L. (1986). Two faces of identity: The "I" and the "we". Journal of Social Issues, 42, 81-98.

Taylor, R. (1991). Poverty and adolescent Black males: The subculture of disengagement. In P. B. Edelman \& J. Ladner (Eds.), Adolescence and poverty: Challenge for the 1990's (pp. 139-162). Washington, DC: Center for National Poway Press.

Taylor, R. L. (1989). Black youth, role models, and the social construction of identity. In R. L. Jones (Ed.), Black adolescents (pp. 155174). Berkeley, CA: Cobb \& Henry.

Thornton, M., Chatters, L., Taylor, R., \& Allen, W. (1990). Sociodemographic and environmental correlates of racial socialization by Black parents. Child Development, 61, 401-409.

Trew, K., \& Benson, D. E. (in press). Dimensions of social identity in Northern Ireland. In G. Breakwell \& E. Lyons (Eds.), Changing European identities: Social psychological analyses of social change. London: Pergamon.

Tripp, L. (1991). Race consciousness among African-American students, 1980s. The Western Journal of Black Studies, 15, 159-168.

Turner, J. C., Hogg, M. A., Oakes, P. J., Reicher, S. D., \& Wetherell, S. M. (1987). Rediscovering the social group: A self-categorization theory. Oxford, England: Basil Blackwell.

Turner, J. C., Oakes, P. J., Haslam, S. A., \& McGarty, C. (1994). Self and collective: Cognition and social context. Personality and Social Psychology, 20, 454-463.

West, C. (1993). Oppositional gaze: Distorted images of African-American women. Paper presented at the 101st Annual Convention of the American Psychological Association, Toronto, Ontario, Canada.

Wilson, W. J. (1987). The truly disadvantaged. Chicago: University of Chicago Press.

Received October 31, 1994

Revision received April 17, 1995

Accepted April 29, 1995 